\title{
Issues in Feedback Learning
}

\author{
Rahman Bin Abdullah \\ Faculty of Hotel \& Tourism, \\ Universiti Teknologi MARA, \\ Cawangan Terengganu, 23000, Dungun, Terengganu
}

Harnizam Zahari

Faculty of Hotel \& Tourism, Universiti Teknologi MARA, Cawangan Terengganu, 23000, Dungun, Terengganu

\author{
Razlan Adli Zain \\ Faculty of Hotel \& Tourism, \\ Universiti Teknologi MARA, \\ Cawangan Terengganu, 23000, Dungun, Terengganu
}

\author{
Nazarudin Derani \\ Faculty of Hotel \& Tourism, \\ Universiti Teknologi MARA, \\ Cawangan Terengganu, 23000, Dungun, Terengganu
}

\author{
Nik Adnan Nik Mat \\ Faculty of Hotel \& Tourism, \\ Universiti Teknologi MARA, \\ Cawangan Terengganu, 23000, Dungun, Terengganu
}

\begin{abstract}
Feedback learning is one of the major tools in educational programs improvisation and educational reforms. The complexity of feedback learning issues could not be understated, since many aspect of educational reforms and students improvisation rely on the feedback they received and given. There are many issues clouding the feedback learning and feedback giving process, which will be discussed over here. But, the debate eventually leads to betterment of the process and eventually acknowledging feedback learning as a very useful and productive tools either to the educational organization providing it or the students receiving it.
\end{abstract}

Keywords: Feedback learning, timing, assessment, educational institutions

\section{INTRODUCTION}

Feedback learning is one of the elements that are used in many education institutions as a tool to improvise student's performances and their syllabus content. However, feedback learning process and its quality is seriously facing inadequacies from improper rubrics development, no standardized assessment, and dissimilar assessment perspectives from different lecturers'. In addition to that, the usage of papers to produce plenty assessment forms is seen to be quite outdated and cost accumulating in the long run. 
Although many aspects of feedback learning are still quite argumentative and subjective in nature, it is mutually agreed upon that the importance and relevance of feedback learning is something that any educational organization could not walk away from. The assistance of technology further helps in enhancing the quality and delivery of feedback either to the students or the organization in large.

\section{LITERATURE REVIEW}

An individual going through an active learning process usually constructs their own interpretation and understanding of the learned subject. This is further supported by Vygotsky (1978) that indicate an individual's knowledge construction can be much enhanced and improvised under proper tutelage of an adults or peers. In higher learning institutions, lecturers are shouldering this responsibility to students through means of feedback in formative assessments. Several studies have shown and highlight the importance of wellplanned feedback that enables student improvisation (Sadler, 1998; Falchikov, 1995; Stefani, 1998; Weaver, 2006). A well planned syllabus with assessment would be able to produce an articulate grading system, thus, create rooms of improvisation by providing feedback either towards the students or the assessors. However, feedback in learning institutions or educational programs possess different interpretation, according to each of their respective perspectives.

Abundance definitions and characterizations exist in defining feedback and feedback learning process. Feedback is defined as "all dialogue to support learning in both formal and informal situations" (Askew \& Lodge, 2000). In addition to that, according to Ramaprasad (1983), "feedback is information about the gap between the actual level and the reference level of a system parameter which is used to alter the gap in some way". It is important to clarify the many definition of feedback that exists in the literature. In this paper, the definition stands as "feedback as a process that guides students to close the gap between their current and desired performance".

In terms of formative assessment, there are studies that have shown learning and feedbacks are positively interrelated (Orsmond, Merry, \& Reiling, 2000) and that feedback provided through formative assessments do motivate students and enhance their learning (Yorke, 2003). Positive feedback can have significant impact on student learning (Young, 2000; Nicol \& MacFarlane Dick, 2006). Some studies show increased levels of motivation through feedback, as it helps them in two ways: reinforcing and recognizing their efforts in the learning process (Hyland, 2000; Marzano, Pickering, \& Pollock, 2001). While positive feedback is noted for its enhancing effects, while negative feedback on the contrary does diminish students' engagement and motivation (Alton Lee, 2003).This basically relates to the condition of improper feedback to the students or misunderstanding between the students and the assessors which leads to negative feedback giving environment. On the other hand, it is also highlighted by some authors (E.G., Orsmond, Merry, \& Reiling, 2002) that providing positive and negative feedback should lead students to a deeper understanding of the topic/ subject matter. The feedback received, either positive or negative should be able to produce an input which is useful to the students, although the extent they are taking it to improvise their work is a very subjective field.

In terms of timely feedback, a good deal of discussion exists in the literature on enhanced student learning (Tshibalo, 2005; Trotter, 2006; Hattie \& Timperley, 2007). The core aim of feedback is to increase students' understanding of their knowledge or skill in a specific or general area of content that is part of the learning objectives and outcomes (Retna \& Cavana, 2013). One important consideration is when to give students their feedback and what is a good 
timeframe for it. One view strongly advocates that feedback is only useful to students if it is given in a timely fashion (Weaver, 2006). This is to avoid students making further incorrect assumptions, confusions or errors as feedback is conceptualized as reinforcement (Paige, 1966; Sullivan, Schutz, \& Baker, 1971; Gibbs, 2002). In comparison, there are studies that claim that delayed feedback is more useful than immediate feedbackfor learning and retention of knowledge and skills for students (Butler, Karpicke, \& Roediger, 2007). On the other hand (e.g., Butler \& Henry, 2008) suggest that the correct timing of giving feedback, both immediate and delayed, has positive learning impacts for students. The importance of giving feedbacks in the right time frame is still a cause for concern in higher education, as in some instances students only get their feedback after completion of their courses (Gibbs, 2006). In order to overcome this issue, formative assessment needs to be planned in such a manner where students can get their feedback and use it for improving their learning before their final examination or at the end of the course (Trotter, 2006). The use of technology can aid in the provision of timely feedback (Ribchester, France, \& Wakefield, 2008). The process of giving feedback in a timely manner is still a matter of subjective discussion. However, each individual educational institution and learning programs should customized their feedback giving in accordance to their nature and subject matter.

According to William (2007), feedback must enable students to act on current or future learning outcomes (William \& Black, 1996). He further highlighted that it is imperative for lecturers to ensure students take necessary action in order to close the feedback gap loop (Sadler, 1989). The inability to close the gap either by students or lecturers may results in feedback being irrelevant. Although there's a lot of time and intellectuals thinking being spent in order to provide feedback for the students to improvise, it is a worthy effort in enhancing learning in higher learning institution (Hattie \& Timperley, 2007), and the failure of taking any action, makes it a huge waste.

Although feedback is important for the learning process, the quality of feedback should not be understated. (Retna \& Cavana, 2013). Comprehensibility, poor handwriting (Race, 2001), inadequate information (Carless, 2006), judgmental comments (James, McInnis, \& Devlin, 2002) and grading without any written comments (Swann \& Arthur, 1998) are a few examples that affect the quality of feedback to students. The main objectives of feedback is to enable learning in a manner that students are able to understand their current ability of a particular module, and to further improve and close the gap between their actual and required performances (Retna \& Cavana, 2013). The discussion above shows that feedback and its quality are equally important in order to allow improvisation of the learning process and the increment of the teaching quality. Thus, providing feedbacks in any subjects learning outcomes should be taken seriously and cohesively.

The discussion above indicates that in order for universities to improvise on their respective modules and programs, teaching and learning processes, attention should be placed and exercised in feedbacks of each subjects. Although there are differing opinions in many aspects, timing being the main area of disagreement, there is a huge consensus agreement of the importance and value of feedback either for the students or the programs itself. An effective feedback is something that is still argued, in terms of its timing, formative or summative, quality of the feedback, the approach and much more. On the other hand, it is also agreed consensually that technology helps a lot nowadays in providing feedback and the ability to enhance it to the next level. 


\section{CONCLUSION}

Feedback learning process possess many stages and elements which includes the timing of feedback delivery, its value, the quality, formative versus summative, and its approaches. However, it is well agreed upon that the existence of technology helps feedback learning to be conducted in well and timely manner. Previously, a practical class with no standard assessment, rubrics and mutual delivery standard by many lecturers makes feedback to the students quite difficult to be delivered. But, the negative aspect of it creates an opportunity to create a system that address and solved all these issues comprehensively. There are many more rooms of improvement as far as the CARES system are concerned, such as rubrics and content improvisation. But for now the main issues of non-standardization of assessment and the ability to tap the potential of feedback learning process to the students and educational institutions have been achieved.

\section{References}

Alton Lee, A. (2003). Quality teaching for diverse students in schooling: Best evidence synthesis. Wellington, New Zealand: Ministry of Education

Askew , S., \& Lodge, C. (2000). Gifts, ping pong and loops linking feedback and learning. In S. Askew (Ed), Feedback for learning (pp. 1-17). London, UK: Routledge.

Butler, A. C., Karpicke, J.D., \& Roediger, H.L. III (2007). The effect of type and timing of feedback on learning from multiple choice tests. Journal of Experimental Psychology: Applied, 13, 273-281.

Butler, A.C., \& Henry, L.R. III (2008). Feedback enhances the positive effects and reduces the negative effects of multiple choice testing. Memory \& Cognition, 36 (3), 604-616.

Carless, D. (2006). Differing perceptions in the feedback process. Studies in Higher Education, 31(2), 219-233.

Falchikov N. (1995). Improving feedback to and from students. In P. Knight (Ed) Assesment for learning in higher education (pp. 157-166). London, UK: Kogan Page

Gibbs, G. (2002). Evaluating the impact of formative assessment on student learning behavior. Invited address: earli-Northumbia Assessment Conference, 28-30 August.

Gibbs, G. (2006). How assessment frames student learning . In C. Bryan \& K. Clegg (Eds), Innovative assessment in Higher Education (pp. 23-36). London, UK: Routledge.

Hattie, J., \& Timperley, H. (2007). The power of feedback. Review of Educational Research, 77(1), 81-112.

Hyland, P. (2000). Learning from feedback on assessment. In P. Hyland \& A. Booth (Eds), The practice of university history teaching (pp. 233-247). Manchester University Press.

James, R., McInnis, C., \& Devlin, M. (2002). Assessing learning in Australasian universities: Ideas, strategies and resources for quality in student assessment. Melbourne, Vic, Australia: Centre for study of Higher Education, University of Melbourne.

Nicol, D. J., \& MacFarlane Dick, D. (2006). Formative assessment and self-regulated learning: A model and seven principles of good feedback practice. Studies in Higher Education, 31 (2), 199- 218.

Marzano, R., Pickering, D., \& Pollock,J. (2001). Classroom instruction that works: Research based strategies for increasing student achievement. Alexandria, VA: Association for Supervision and Curriculum Development.

Orsmond, P., Merry S., \& Reiling, K. (2000). The use of student derived marking criteria in peer and selfassessment. Assessment \& Evaluation in Higher Education, 25(1), 21-38

Orsmond, P., Merry, S., \& Reling, K. (2002). The student use of formative feedback in their learning. Paper presented at the Learning Communities and Assessment Cultures Conference. England: University of Northumbia.

Paige, D.D. (1966). Learning while testing. Journal of Educational Research, 59, 276-370.

Ramaprasad, A. (1983). On the definition of feedback. Behavioral Science, 28, 4-13.

Race, P. (2001). Using feedback to help students to learn. Heslington, York, UK: The Higher Education Academy.

Retna, K.S, \& Cavana, R.Y. (2013). Undergraduate management students' perceptions of feedback in a New Zealand university. Journal of Management \& Organization. Cambridge University Press and Australian and New Zealand Academy of Management. 
Ribchester, P., France, D., \& Wakefield, K. (2008). It was just like a personal tutorial: Using podcasts to provide effective feedback. Paper presented at the Higher Education Academy Conference, July.

Sadler, D.R. (1989). Formative assessment and the design of instructional systems. Instructional Science, 18, 119144

Stefani, L. J. (1998). Assessment in partnership with learners. Assessment and Evaluation in Higher Education 23 339-350

Sullivan, H. J., Schutz, R.E., \& Baker, R.L. (1971). Effects of reinforcement contingencies. American Educational Research Journal,8, 135-141.

Swann, J., \& Arthur, J. (1998). Empowering lecturers: A problem based approach to improving assessment practice. Higher Education Review, 31(2), 50-74

Trotter, E. (2006). Student perceptions of continuous summative assessment. Assessment \& Evaluation in Higher Education, 31,505-521.

Tshibalo, A.E. (2005). Computer aided assessment and its potential impact on teaching and learning in higher education. Paper presented at the Making A Difference: 2005 Evaluations and Assessment Conference, Sydney, Australia, December.

Vygotsky, L. S. (1978). Mind in Society. London, UK: Harvard University Press

Weaver, M. R. (2006). Do students value feedback?Student perceptions of tutors written responses. Assessment \& Evaluation in Higher Education, 31 (3), 379-394.

William, D., \& Black, P. (1996). Meanings and consequences: A basis for distinguishing formative and summative functions of assessment? British Educational Research Journal. 22(5), 537-548.

William, D. (2007). Keeping learning on track: Classroom assessment and the regulation of learning. In F. Lester Jr. (Ed), Second handbook of research on mathematics teaching and learning(pp. 1053-1098). Greenwich, CT: Information Age Publishing.

Yorke, M. (2003). Formative assessment in higher education: Moves towards theory and the enhancement of pedagogic practice. Higher Education, 45, 477-501.

Young, P. (2000). "I might as well give up"; Self esteem and mature students' feelings about feedback on assignments. Journal of Further and Higher Education., 24(3), 409-418. 